\title{
Effects of Heat-Treatment on the Microstructure and Wear Resistance of a High-Chromium Cast Iron for Rolls
}

\author{
Zhi-hong Guo, ${ }^{1,2}$ Fu-ren Xiao, ${ }^{1}$ Su-ling Lu, ${ }^{2}$ Han-yun Li, ${ }^{3}$ and Bo Liao \\ ${ }^{1}$ Key Lab of Metastable Materials Science \& Technology and College of Material Science \& Engineering, \\ Yanshan University, Qinhuangdao 066004, China \\ ${ }^{2}$ Hebei Key Laboratory of Material Near-Net Forming Technology and College of Material Science and \\ Engineering of Hebei University of Science and Technology, Shijiazhuang 050000, China \\ ${ }^{3}$ Xingtai Zheng Kun Machinery \& Mill Roll Co. Ltd., Xingtai 055450, China \\ Correspondence should be addressed to Bo Liao; laorll@aliyun.com
}

Received 14 June 2016; Revised 17 August 2016; Accepted 1 September 2016

Academic Editor: Katsuyuki Kida

Copyright (c) 2016 Zhi-hong Guo et al. This is an open access article distributed under the Creative Commons Attribution License, which permits unrestricted use, distribution, and reproduction in any medium, provided the original work is properly cited.

\begin{abstract}
The variations of microstructure and mechanical properties of a high-chromium cast iron for rolls were studied from as-cast to the final heat treatments. Results show that the as-cast microstructure of the $\mathrm{HCCI}$ consists of $\mathrm{M}_{7} \mathrm{C}_{3}$ carbide, $\mathrm{M}_{23} \mathrm{C}_{6}$ carbide, martensite matrix, and retained austenite. The large dendritic $\mathrm{M}_{7} \mathrm{C}_{3}$ carbide surrounds the matrix, and the $\mathrm{M}_{23} \mathrm{C}_{6}$ carbide is mainly distributed in the matrix. Part of $\mathrm{M}_{23} \mathrm{C}_{6}$ carbide transforms to $\mathrm{M}_{7} \mathrm{C}_{3}$ carbide and is dissolved in austenite during austenization at $1020^{\circ} \mathrm{C}$. Thus, the amount of $\mathrm{M}_{23} \mathrm{C}_{6}$ carbide decreases, whereas that of $\mathrm{M}_{7} \mathrm{C}_{3}$ carbide increases after quenching; the highest hardness is also obtained. After tempering, the martensite transforms to a tempered martensite, and some carbide precipitates in the martensite matrix. The hardness also changes from HRC62.1, which corresponds to quenching, to HRC55.2 and HRC56.3, which correspond to once and twice tempering, respectively. However, tempering could improve the impact toughness and wear resistance of the HCCI.
\end{abstract}

\section{Introduction}

High-chromium cast iron (HCCI), as excellent wear-resistant material, has been widely used for hot rolling working roller since the end of the last century [1-4]. The exceptional wear resistance of HCCIs is attributed primarily to the high volume fraction of hard eutectic chromium carbides $[5,6]$. The high volume fraction of hard and consecutive eutectic chromium carbides results in a fatal defect of low impact toughness [7]. Heat treatments are useful methods to change the matrix microstructure for the improvement of impact toughness and wear resistance for numerous cast iron materials. These treatments provide relatively few benefits in improving the impact toughness of the HCCI with even larger amount of hard consecutive eutectic chromium carbides [8]. Therefore, several research works use alloying to improve the toughness and wear resistance of HCCI rolls; consequently, the improved HCCI rolls with the addition of $\mathrm{Mn}, \mathrm{Mo}, \mathrm{V}, \mathrm{Ti}$, and $\mathrm{Nb}$ were developed [9-13]. However, further improvement on the toughness and wear resistance of the improved HCCI rolls is still necessary to understand the variation of microstructure during heat treatment and its effects on toughness and wear resistance.

In this work, the variation of microstructures and mechanical properties from as-cast to heat treatment of a $\mathrm{HCCI}$ with $22 \% \mathrm{Cr}$ and some $\mathrm{Mo}, \mathrm{V}$, and $\mathrm{Ni}$ alloying elements was studied. The results are beneficial for process optimization and improvement of the mechanical properties of the HCCI rolls.

\section{Materials and Procedures}

The roll is a small wok roll, normally prefabricated by uphill casting a layer of wear-resistant material (HCCI) on the outside surface of the 1045 steel sleeve as the roll sleeve, and then the spindle is installed by means of interference fit. Figure 1 is the casting process schematic representation, the actual picture, and design parameters of roll sleeve. From Figure $1(\mathrm{a})$, the casting system has ten parts. The rough processing roll sleeve is the casting in the middle between two lines 
TABLE 1: Chemical composition of high-chromium cast iron (HCCI; mass percent, \%).

\begin{tabular}{lcccccccccccc}
\hline $\mathrm{C}$ & $\mathrm{Si}$ & $\mathrm{Mn}$ & $\mathrm{P}$ & $\mathrm{S}$ & $\mathrm{Cr}$ & $\mathrm{Ni}$ & $\mathrm{Mo}$ & $\mathrm{V}$ & $\mathrm{W}$ & $\mathrm{Nb}$ & $\mathrm{Cu}$ & $\mathrm{Fe}$ \\
\hline 2.16 & 1.65 & 0.48 & 0.05 & 0.03 & 22.0 & 1.23 & 0.96 & 1.18 & 0.15 & 0.11 & 0.39 & balance \\
\hline
\end{tabular}

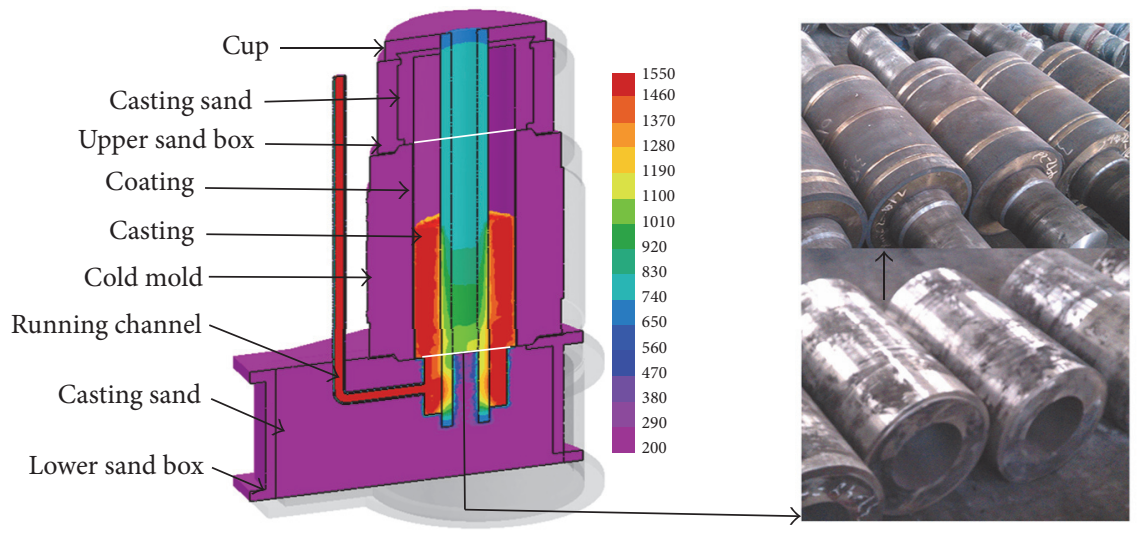

(a)

(b)

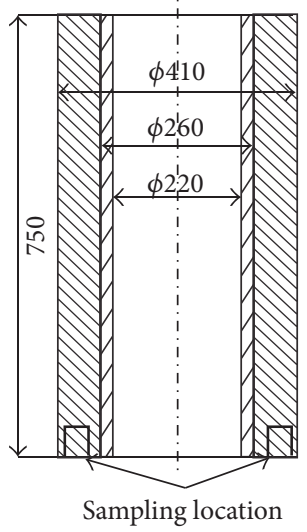

(c)

FIgURE 1: The schematic representation (a) and the actual picture and (b) the design parameters of roll sleeve (c).

(cold mold part) in Figure 1(a), showed in the lower half of Figure 1(b), and its size is shown in Figure 1(c). The thickness of the high-chromium cast iron is $75 \mathrm{~mm}$. The experimental material of as-cast HCCI was cut down from the bottom end showed in Figure 1(c). The thickness of the ring was $20 \mathrm{~cm}$.

The real chemical composition of the alloy was shown in Table 1 . Heat treatment consisted of austenizing at $1020^{\circ} \mathrm{C}$ for $4 \mathrm{~h}$, followed by tempering twice at $500^{\circ} \mathrm{C}$ for $4 \mathrm{~h}$. The quenching and tempering furnace used was KSL-1700X-A2 silicon-kryptol resistance furnace controlled by a microcomputer, with the difference in temperature of $\pm 1^{\circ} \mathrm{C}$. After heat treatment, the microstructures, hardness, impact toughness, and impact abrasive wear properties of all specimens were studied. The test surface located at about $10 \mathrm{~mm}$ from the outside surface of the ring. The specimens with the dimensions of $10 \mathrm{~mm} \times 10 \mathrm{~mm} \times 20 \mathrm{~mm}$ for metallographic examination were mechanically polished and etched with $4 \%$ nital solution and observed using an Ultra 55 scanning electron microscope (SEM). The phase structures of specimens were determined with a D/max-2500/PC X-ray diffractometer (XRD). The rolling wear test was conducted on impact wear testing machine with the dimensions of $\phi 10 \mathrm{~mm} \times 40 \mathrm{~mm}$, and the tested conditions were as follows: impact load, $10 \mathrm{~kg}$; impact hammer stroke, $36 \mathrm{~mm}$; abrasive material, quartz sand with size of 10-12 orders; and flow rate of sand, $45 \mathrm{~kg} / \mathrm{h}$. The toughness of samples was carried out on a ZBC5404 pendulumtype impact tester with the dimensions of $10 \mathrm{~mm} \times 10 \mathrm{~mm} \times$ $55 \mathrm{~mm}$, without gap. The hardness, impact toughness, and impact abrasive wear properties of all specimens were the average of five test runs.

\section{Results and Discussion}

3.1. Microstructure. Figure 2 shows the XRD patterns of the specimens after different heat treatments. The phases of the HCCI mainly consist of martensite, retained austenite, and chromium carbides of $\mathrm{M}_{7} \mathrm{C}_{3}$ (PDF: 17-0333) and $\mathrm{M}_{23} \mathrm{C}_{6}$ (PDF: 5-0721) [14]; some differences could also be found in different specimens. For the as-cast specimen, the diffraction peak intensities of retained austenite and $\mathrm{M}_{7} \mathrm{C}_{3}$ phases are higher than those of other specimens. After quenching and tempering, the diffraction peak intensity of retained austenite and $\mathrm{M}_{23} \mathrm{C}_{6}$ phases decreased, whereas that of $\mathrm{M}_{7} \mathrm{C}_{3}$ phase increased. These results indicate that some $\mathrm{M}_{23} \mathrm{C}_{6}$ phases are dissolved in austenite or transformed to $\mathrm{M}_{7} \mathrm{C}_{3}$ phase during austenization, whereas the phase constituents are slightly changed after tempering.

In addition, the (110) diffraction peak of martensite phase of as-cast specimen is at lowest angle, and it deviates to higher angle after quenching and tempering (Figure 2). This result indicates that the as-cast martensite had higher amount of $\mathrm{C}$ and alloyed elements [15], which could explain the large amount of austenite retained in the as-cast specimen. After tempering, some carbides could precipitate from martensite; consequently, the amount of $\mathrm{C}$ and alloyed elements decreases; hence the diffraction peak of martensite deviates to higher angle.

Figure 3 shows the equilibrium phase diagram and relationship of the content of each phase with the temperature of the HCCI calculated using Thermo-Calc software based on TCFE7 database. During casted cooling processes, austenite began to precipitate from liquid when the temperature dropped to approximately $1320^{\circ} \mathrm{C}$. When the temperature cooled to about $1280^{\circ} \mathrm{C}, \mathrm{M}_{7} \mathrm{C}_{3}$ carbide began to precipitate. The liquid phase, $\mathrm{M}_{7} \mathrm{C}_{3}$ carbide, and austenite coexisted in the molten pool, and the liquid phase subsequently transformed to solid phase continuously. The amount of $\gamma$ Fe reached the maximum when the temperature decreased to about $1275^{\circ} \mathrm{C}$. With the further decrease of temperature, the amount of austenite decreased, whereas that of $\mathrm{M}_{7} \mathrm{C}_{3}$ 


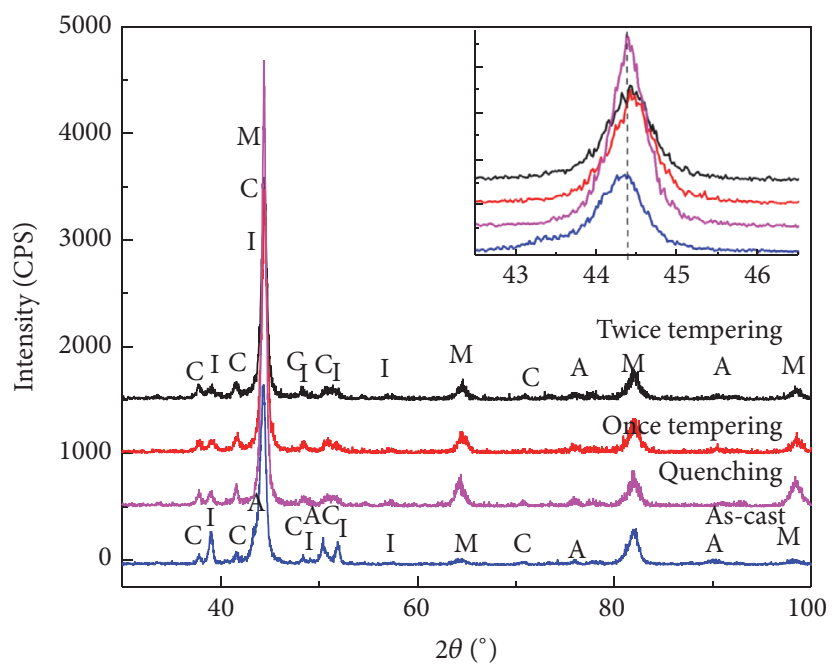

$$
\begin{aligned}
& \text { M: martensite } \\
& \text { A: austenite } \\
& \text { C: } \mathrm{M}_{7} \mathrm{C}_{3} \\
& \text { I: } \mathrm{M}_{23} \mathrm{C}_{6}
\end{aligned}
$$

Figure 2: X-ray diffractometer patterns of the HCCI as-cast and after different heat treatments.

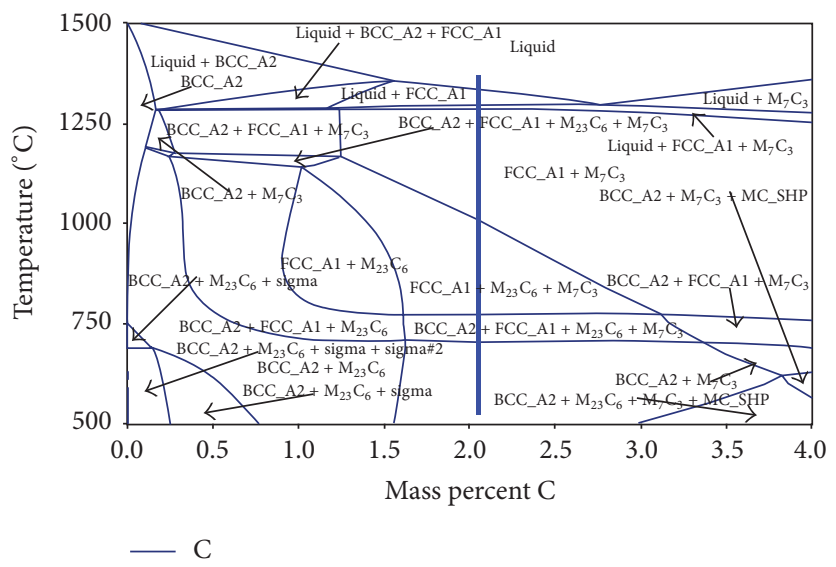

FIGURE 3: Equilibrium phase of the HCCI calculated by Thermo-Calc software based on TCFE7 database.

carbide increased, which indicates that the $\mathrm{M}_{7} \mathrm{C}_{3}$ carbide is precipitated from austenite. When the temperature dropped to about $1085^{\circ} \mathrm{C}$, the amount of austenite and $\mathrm{M}_{7} \mathrm{C}_{3}$ carbide decreased, whereas that of $\mathrm{M}_{23} \mathrm{C}_{6}$ carbide increased; this observation indicates that the austenite and $\mathrm{M}_{7} \mathrm{C}_{3}$ carbide transformed to $\mathrm{M}_{23} \mathrm{C}_{6}$ carbide. Furthermore, when the temperature decreased at approximately $875^{\circ} \mathrm{C}$, the $\mathrm{M}_{23} \mathrm{C}_{6}$ carbide retransformed to $\mathrm{M}_{7} \mathrm{C}_{3}$ carbide. As the temperature dropped from $780^{\circ} \mathrm{C}$ to $700^{\circ} \mathrm{C}$, austenite transformed into ferrite completely, and the $\mathrm{M}_{23} \mathrm{C}_{6}$ carbide transformed to $\mathrm{M}_{7} \mathrm{C}_{3}$ carbide because the amount of $\mathrm{M}_{23} \mathrm{C}_{6}$ carbide decreased, whereas that of $\mathrm{M}_{7} \mathrm{C}_{3}$ carbide increased.

The results illustrated that the equilibrium microstructure of the HCCI consisted of ferrite, $\mathrm{M}_{7} \mathrm{C}_{3}$ carbide, and $\mathrm{M}_{23} \mathrm{C}_{6}$ carbide (Figure 3). However, for the phase structure of the as-cast HCCI, the nonequilibrium microstructure mixture of retained austenite, martensite, $\mathrm{M}_{7} \mathrm{C}_{3}$ carbide, and $\mathrm{M}_{23} \mathrm{C}_{6}$ carbide was obtained, which resulted in the large amount of $\mathrm{M}_{23} \mathrm{C}_{6}$ carbide remaining in the as-cast microstructure (Figure 2). Based on Figure 2, after austenization at $1020^{\circ} \mathrm{C}$, some $\mathrm{M}_{23} \mathrm{C}_{6}$ carbides maybe dissolved in austenite, and some $\mathrm{M}_{23} \mathrm{C}_{6}$ carbide maybe transformed to $\mathrm{M}_{7} \mathrm{C}_{3}$ carbide, which resulted in the decreased amount of $\mathrm{M}_{23} \mathrm{C}_{6}$ carbide, but increased amount of $\mathrm{M}_{7} \mathrm{C}_{3}$ carbide (Figure 2). After tempering at $500^{\circ} \mathrm{C}$, only a small amount of the $\mathrm{M}_{7} \mathrm{C}_{3}$ and $\mathrm{M}_{23} \mathrm{C}_{6}$ carbides maybe precipitated in the matrix (Figure 2); therefore, the amount of $\mathrm{M}_{7} \mathrm{C}_{3}$ and $\mathrm{M}_{23} \mathrm{C}_{6}$ carbides is slightly changed (Figure 2).

Figure 4 shows the microstructures of the specimens of HCCI as-cast and after different heat treatments. A large amount and size of carbide existed in the microstructure of the as-cast specimen, and the dendritic carbides surrounded 

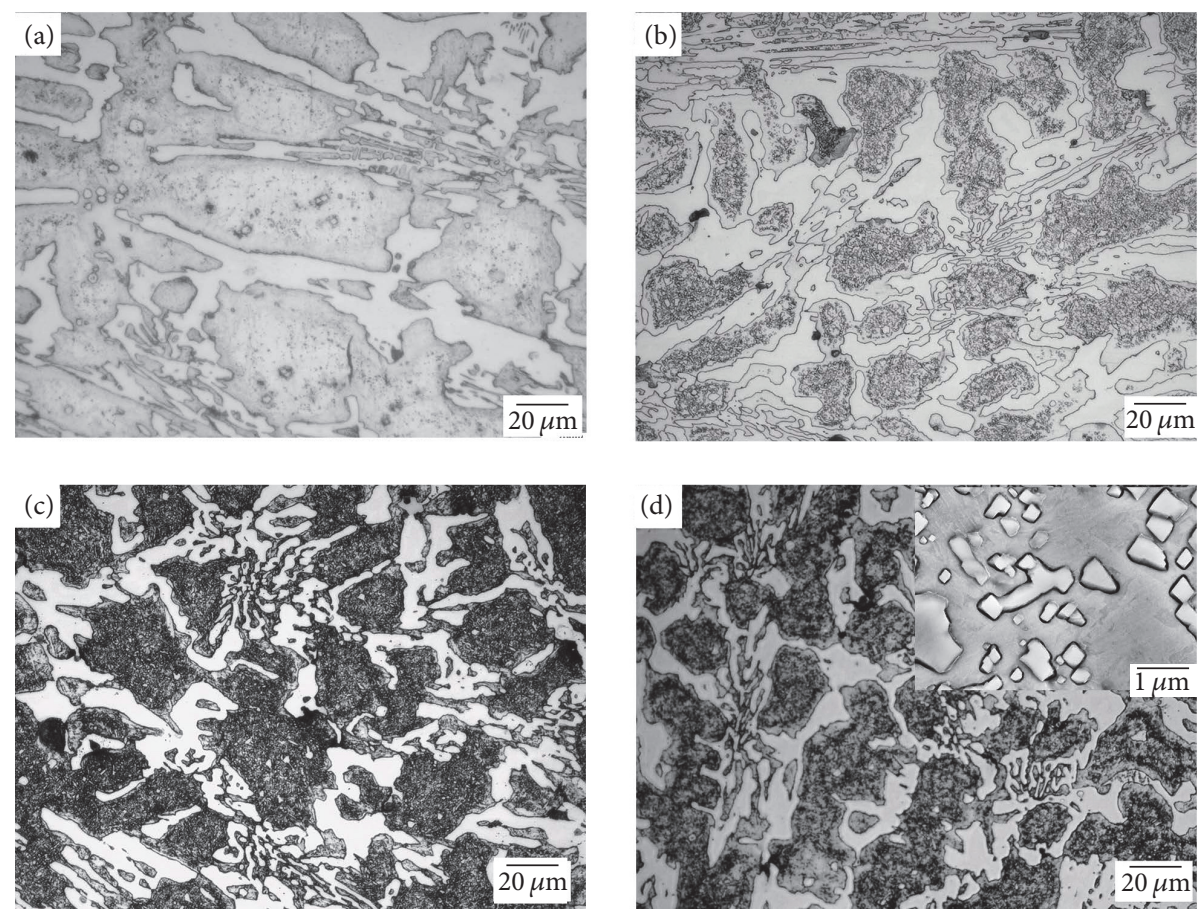

FIGURE 4: Microstructure of specimens: (a) as-cast, (b) quenching, (c) once tempering, and (d) twice tempering.
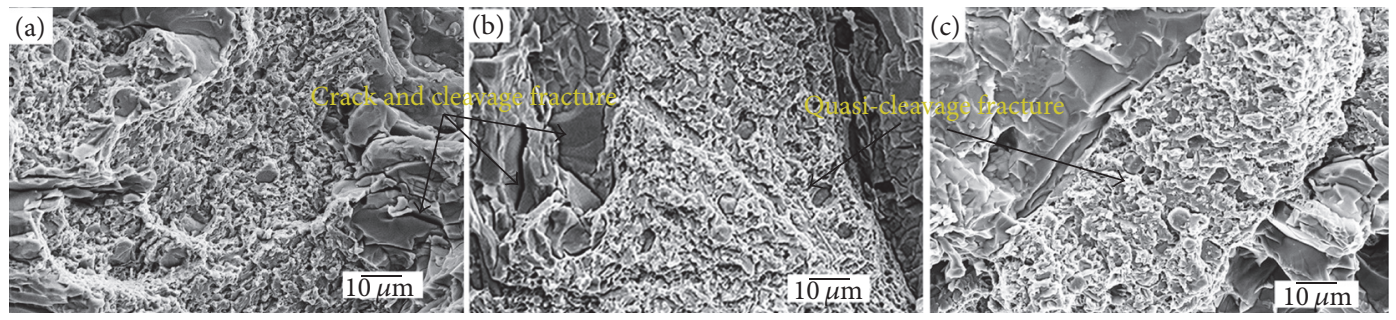

FIGURE 5: Scanning electron microscopy (SEM) impact fracture micrographs of the specimens after (a) quenching, (b) once tempering, and (c) twice tempering.

the matrix (Figure 4(a)). Compared with the XRD results, the large size carbide may be eutectic $\mathrm{M}_{7} \mathrm{C}_{3}$ carbide, and the matrix is a mixture of martensite and retained austenite. In addition, many different sizes and shapes of carbide particles could be observed in the matrix; these particles may be mainly carbide of $\mathrm{M}_{23} \mathrm{C}_{6}$ precipitated during cooling after cast solidification (Figure 4(a)).

After quenching, the amount and shape of the eutectic $\mathrm{M}_{7} \mathrm{C}_{3}$ carbides slightly changed, whereas the larger carbide particles in martensite matrix disappeared. The carbide became uniform and small particles, which indicates that some of $\mathrm{M}_{23} \mathrm{C}_{6}$ in the matrix was dissolved in austenite during quenching and holding processes (Figure 4(b)). The tempering had little effect on eutectic $\mathrm{M}_{7} \mathrm{C}_{3}$ carbide; it only affected the martensite matrix. The matrix changed to tempered martensite, and some carbide was precipitated in the martensite matrix (Figures 4(c) and 4(d)). With the increase of tempering times, the change of matrix microstructure was not observed notably; however, the amount and size of precipitated carbide increased. The average size of precipitated carbide with square-like and/or rod-like shape was about $1.64 \mu \mathrm{m}$ after twice tempering (Figure 4(d)). The variation of matrix microstructure may be a main factor affecting the mechanical properties of the HCCI after heat treatments.

3.2. Impact Toughness and Wear Properties. Table 2 shows the Rockwell hardness and impact toughness of HCCI after heat treatments. The Rockwell hardness of the HCCI increased after quenching; this hardness decreased after once tempering and increased after twice tempering. The impact toughness had the lowest value after quenching, but tempering could improve toughness. Heat treatment provides relatively few benefits for the hardness and toughness because large amount of carbide existed in the microstructure of the HCCI (Figure 4), which could be confirmed by the SEM fracture observation. Figure 5 shows the SEM impact fracture micrographs of the specimens after quenching and tempering. Two kinds of typical fracture morphologies existed, which correspond to the carbide and matrix fracture zones. In the carbide fracture zone, the fracture surface is shown 


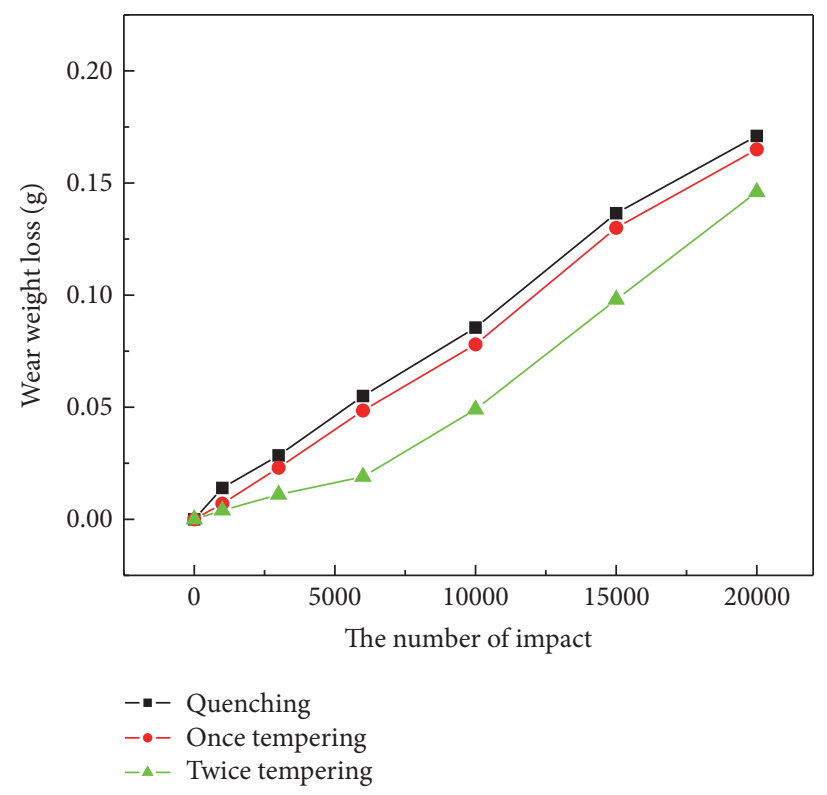

FIGURE 6: Weight losses of the specimens after different heat treatments.

TABLE 2: Hardness and impact toughness of specimen.

\begin{tabular}{lcccc}
\hline & As-cast & Quenching & $\begin{array}{c}\text { Once } \\
\text { tempering }\end{array}$ & $\begin{array}{c}\text { Twice } \\
\text { tempering }\end{array}$ \\
\hline Hardness/HRC & 51.3 & 62.1 & 55.2 & 56.3 \\
Impact toughness/J & 4.5 & 4.1 & 4.3 & 6.0 \\
\hline
\end{tabular}

as a typical cleavage fracture characteristic, and the crack extended randomly. In the matrix fracture zone, the fracture surface is shown as a main quasi-cleavage fracture characteristic, and few cracks could be observed. Some differences also existed in the specimens after quenching and tempering. In the quenching specimen, many blocks peeled off as crack passed the boundary between carbide and martensite matrix; moreover, some small cleavage facets existed in the martensite matrix, which corresponds to the carbide. This result indicates that the quenched martensite matrix had higher brittleness, and the crack easily passed through the carbide and martensite matrix (Figure 5(a)). After tempering, the toughness of martensite matrix was improved, and some large second cracks appeared in the boundary between carbide and martensite matrix (Figures 5(b) and 5(c)). In addition, the amount of small cleavage facets existing in the martensite matrix increased, which indicates that the amount of precipitated carbide increased; this finding corresponds to that of the microstructure observation (Figure 4).

Figure 6 shows the wear weight loss of the specimens after different heat treatments. The weight loss of all specimens increased with increasing impact times, with the highest value after quenching. After tempering, the weight loss of the specimens decreased. The weight loss of the twice-tempered specimen was lower than that of once-tempered specimen. These results show that the wear resistance of the HCCI was improved by once tempering and twice tempering. The change of the wear resistance of the HCCI is attributed to the variation of the microstructure after heat treatment, which could be confirmed by the worn surfaces at SEM observation.

Figure 7 shows the SEM morphology of the worn surface of the specimen after different heat treatments. For the quenched specimen, the worn furrows were wider and deeper (Figure $7(\mathrm{a})$ ), and large worn pieces were cut off from the worn surface by impact wear (Figure $7(\mathrm{~d})$ ) because of the brittleness of the quenched martensite and carbide (Table 2). After once tempering, the worn furrows became nonuniform, and some narrower and deeper worn furrows appeared on the worn surface (Figure 7(b)); furthermore, the worn piece size decreased, and some deeper pits were observed on the worn surface (Figure $7(\mathrm{e})$ ). In once-tempered specimen, the lower hardness decreased the wear resistance, whereas the improved toughness decreased the worn piece size (Table 2, Figures 7(b) and 7(e)); consequently, the weight loss was decreased, and the wear resistance was improved (Figure 6). After twice tempering, the worn surface became smooth, and the worn furrows became wider and shallower (Figure 7(c)). The worn piece size became uniform (Figure 7(f)). These results are attributed to the increase of hardness and impact toughness after tempering (Table 2). The tempering had little effect on eutectic $\mathrm{M}_{7} \mathrm{C}_{3}$ carbide; it only affected the martensite matrix. The matrix changed to tempered martensite, and some carbide was precipitated in the martensite matrix. The second carbides precipitated from the residual austenite. The martensite and residual austenite zone's lost weight is reduced because tiny carbide can protect matrix well. Based on the above mentioned results, hardness is not an important factor that affects the impact wear resistance of the HCCI. However, the impact wear resistance of the HCCI strongly depended on impact toughness; therefore, increasing impact toughness and hardness would effectively improve the impact wear resistance of the HCCI [16]. 


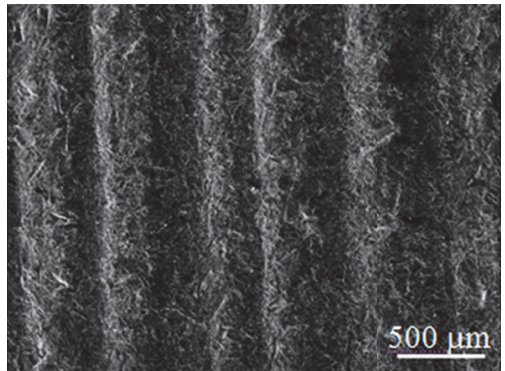

(a)

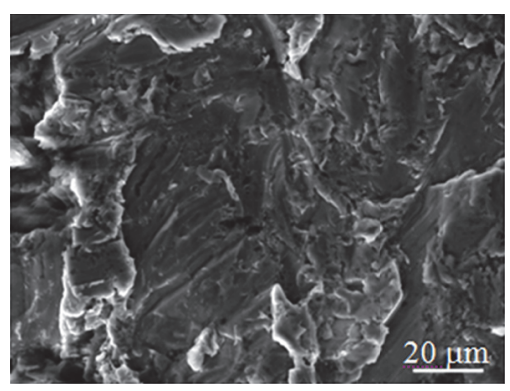

(d)

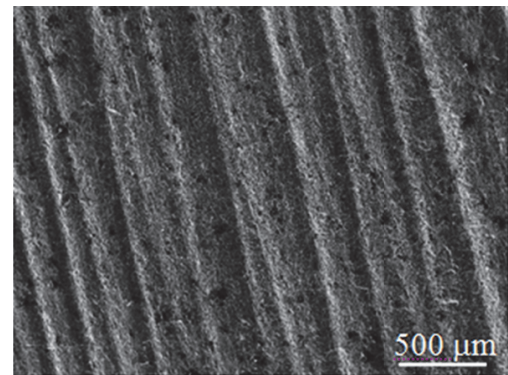

(b)

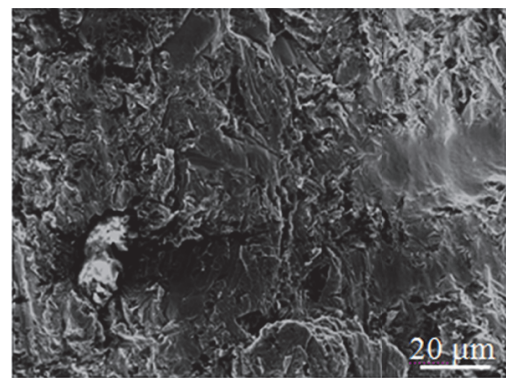

(e)

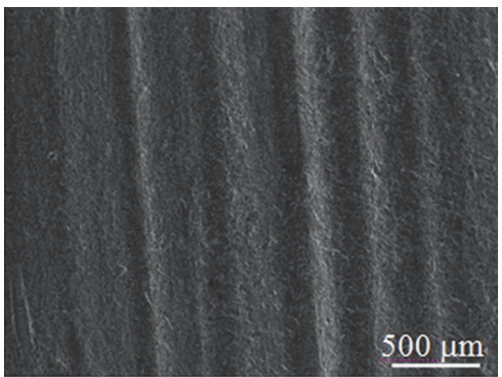

(c)

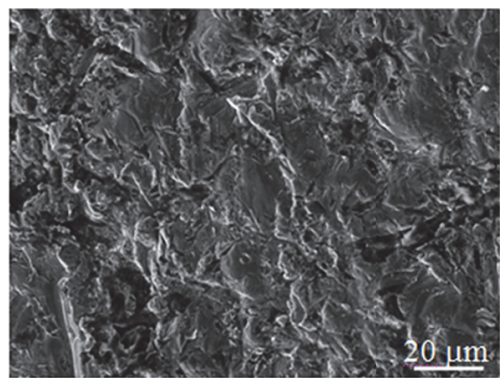

(f)

FIGURE 7: SEM morphology of the worn surface of the specimen after different heat treatments: (a) and (d) quenching, (b) and (e) once tempering, and (c) and (f) twice tempering.

\section{Conclusions}

(1) The as-cast microstructure of the HCCI consists of $\mathrm{M}_{7} \mathrm{C}_{3}$ carbide, $\mathrm{M}_{23} \mathrm{C}_{6}$ carbide, and matrix of mixed martensite and retained austenite. During austenization at $1020^{\circ} \mathrm{C}$, part of $\mathrm{M}_{23} \mathrm{C}_{6}$ carbide transformed to $\mathrm{M}_{7} \mathrm{C}_{3}$ carbide and was dissolved in austenite; thus, the amount of $\mathrm{M}_{23} \mathrm{C}_{6}$ carbide decreased, whereas that of $\mathrm{M}_{7} \mathrm{C}_{3}$ carbide increased. During tempering at $500^{\circ} \mathrm{C}$, the microstructure slightly changed; only a little amount of carbide was precipitated in the matrix, and the martensite matrix transformed to a tempered martensite.

(2) Quenching increased the hardness and decreased the impact toughness. By contrast, tempering increased the impact toughness and decreased the hardness. The impact toughness and hardness were improved with increasing tempering times.

(3) The hardness and impact toughness had a certain effect on wear resistance. The wear weight loss strongly depended on impact toughness; therefore, increasing impact toughness and hardness could improve the wear resistance of the HCCI.

\section{Competing Interests}

The authors declare that there is no conflict of interests regarding the publication of this paper.

\section{Acknowledgments}

This work is sponsored by Hebei Science and Technology Support Program (13274202D) and Hebei University of Science and Technology Fund (XL201002).

\section{References}

[1] X. H. Tang, R. Chung, D. Y. Li, B. Hinckley, and K. Dolman, "Variations in microstructure of high chromium cast irons and resultant changes in resistance to wear, corrosion and corrosive wear," Wear, vol. 267, no. 1-4, pp. 116-121, 2009.

[2] J. H. Ramírez-Ramírez, R. Colás, and N. F. Garza-Montes-deOca, "High temperature oxidation of a work roll grade highchromium white cast iron," Journal of Iron and Steel Research International, vol. 20, no. 10, pp. 122-129, 2013.

[3] Sv. S. Kvon, V. Y. Kulikov, T. S. Filippova, and A. E. Omarova, "Using high-chromium iron as material for production of the equipping components of mine shafts," Metalurgija, vol. 55, no. 2, pp. 206-208, 2016.

[4] L. J. Xu, J. D. Xing, S. Z. Wei, Y. Z. Zhang, and R. Long, "Investigation on wear behaviors of high-vanadium high-speed steel compared with high-chromium cast iron under rolling contact condition," Materials Science and Engineering: A, vol. 434, no. 1-2, pp. 63-70, 2006.

[5] T. Sun, R.-B. Song, X. Wang, P. Deng, and C.-J. Wu, "Abrasive wear behavior and mechanism of high chromium cast iron," Journal of Iron and Steel Research International, vol. 22, no. 1, pp. 84-90, 2015. 
[6] W. K. An, A. H. Cai, Y. Luo et al., "Optimization of composition of as-cast chromium white cast iron based on wear-resistant performance," Materials \& Design, vol. 30, no. 7, pp. 2339-2344, 2009.

[7] G. Xie, H. Sheng, J. Han, and J. Liu, "Fabrication of high chromium cast iron/low carbon steel composite material by cast and hot rolling process," Materials and Design, vol. 31, no. 6, pp. 3062-3066, 2010.

[8] X. Zhi, J. Xing, Y. Gao, H. Fu, J. Peng, and B. Xiao, "Effect of heat treatment on microstructure and mechanical properties of a Ti-bearing hypereutectic high chromium white cast iron," Materials Science and Engineering: A, vol. 487, no. 1, pp. 171-179, 2008.

[9] Z.-P. Sun, B.-L. Shen, J. Wang, H.-H. Liu, and C. Luo, "Effect of manganese on as-cast microstructure and hardening behavior of high chromium white cast iron," Journal of Iron and Steel Research International, vol. 12, no. 1, pp. 34-37, 2005.

[10] S. Imuraia, C. Thanachayanontb, and J. T. H. Pearceb, "Effects of Mo on microstructure of as-cast 28 wt.\% Cr-2.6 wt.\% C-(0-10) wt.\% Mo irons," Materials Characterization, vol. 90, pp. 99-112, 2014.

[11] Y. P. Ma, X. L. Li, D. C. Wang, X. B. Wang, S. F. Song, and X. M. Dang, "Thermodynamics and kinetics study on improving the microstructure of high chromium cast iron by multi-alloying," Journal of Iron and Steel Research International, vol. 19, no. S1, pp. 400-405, 2012.

[12] X. Zhi, J. Xing, H. Fu, and B. Xiao, "Effect of niobium on the ascast microstructure of hypereutectic high chromium cast iron," Materials Letters, vol. 62, no. 6-7, pp. 857-860, 2008.

[13] A. Bedolla-Jacuinde, R. Correa, J. G. Quezada, and C. Maldonado, "Effect of titanium on the as-cast microstructure of a 16\%chromium white iron," Materials Science and Engineering: A, vol. 398, no. 1-2, pp. 297-308, 2005.

[14] K. Weber, D. Regener, H. Mehner, and M. Menzel, "Characterization of the microstructure of high-chromium cast irons using Mössbauer spectroscopy," Materials Characterization, vol. 46, no. 5, pp. 399-406, 2001.

[15] Y. P. Ma, X. L. Li, and L. Yang, "Effects of carbon concentration variation on primary austenite stability of high chromium cast iron," Advanced Materials Research, vol. 154-155, pp. 1684-1688, 2011.

[16] J. J. Coronadoa and A. Gómeza, “Tempering temperature effects on abrasive wear of mottled cast iron," Wear, vol. 267, no. 11, pp. 2070-2076, 2009. 

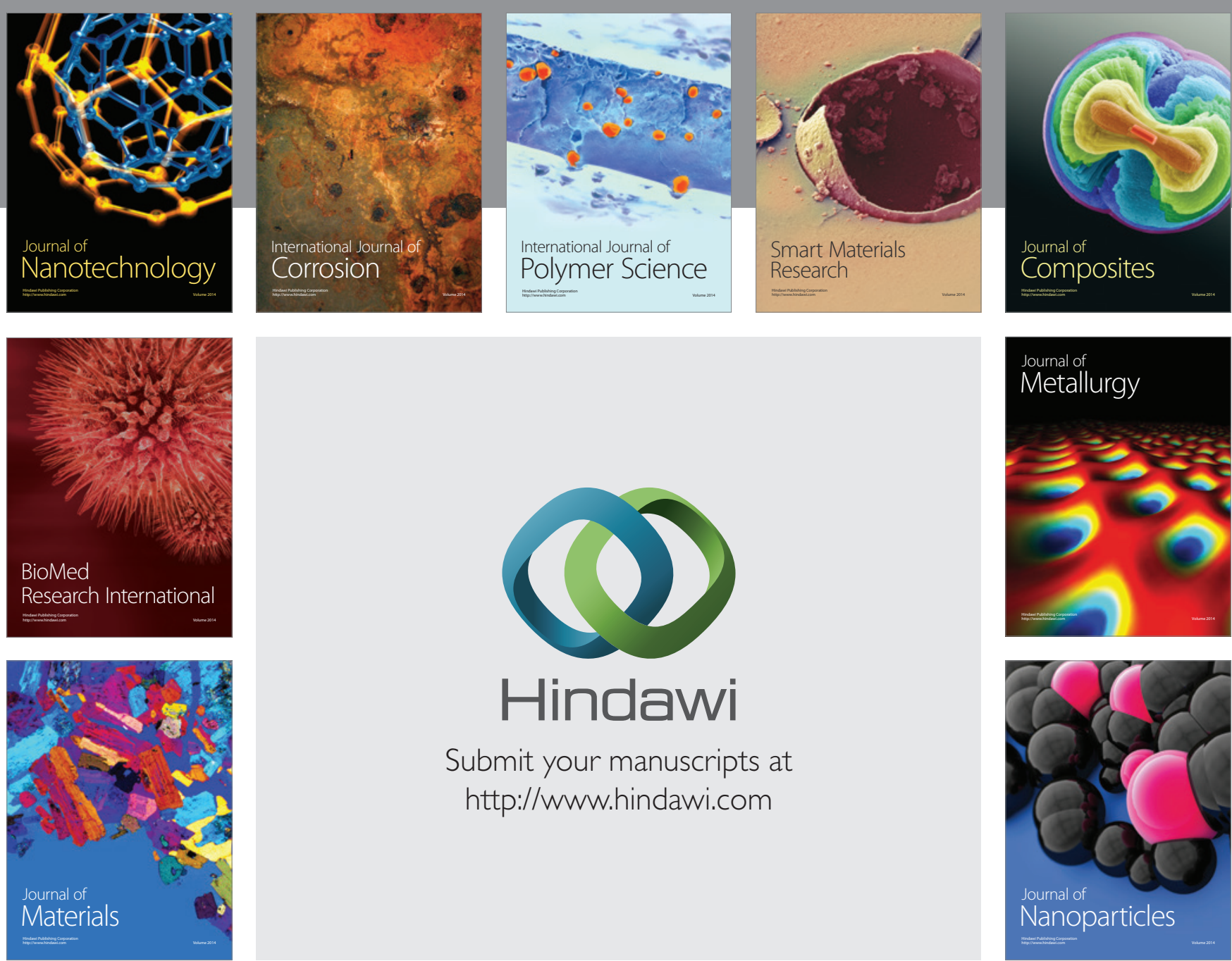

\section{Hindawi}

Submit your manuscripts at

http://www.hindawi.com

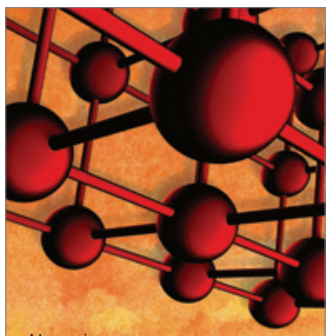

Materials Science and Engineering
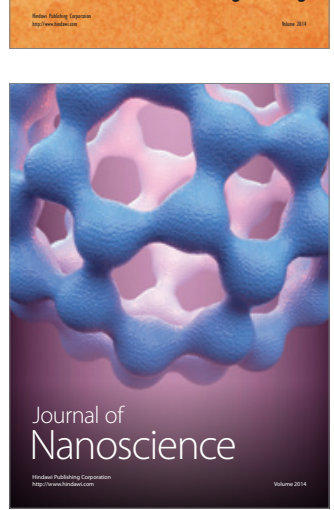
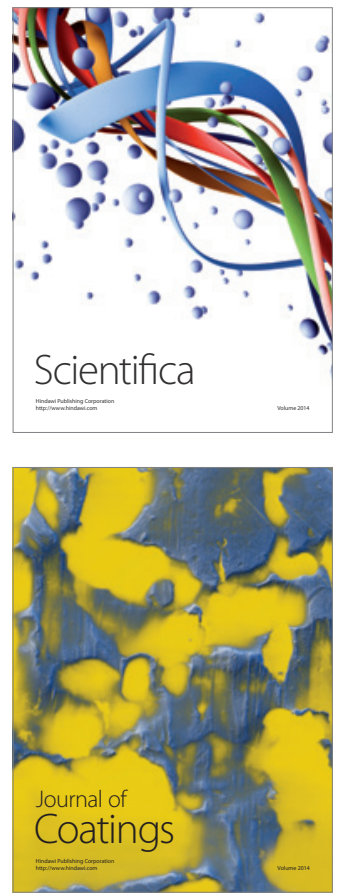
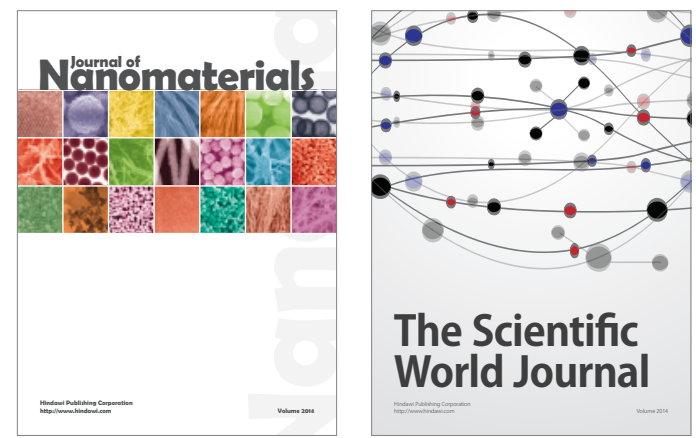

The Scientific World Journal
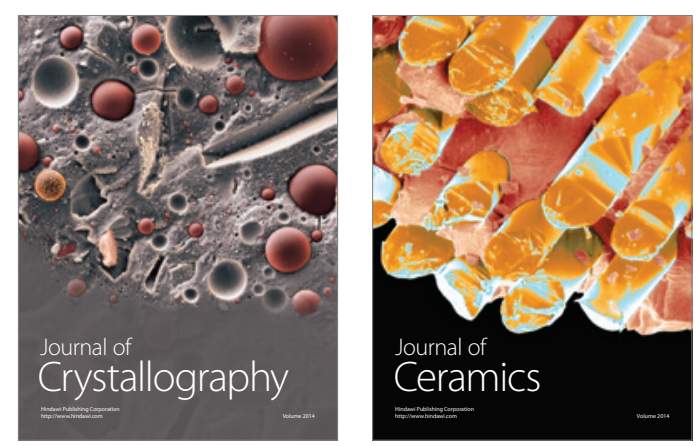
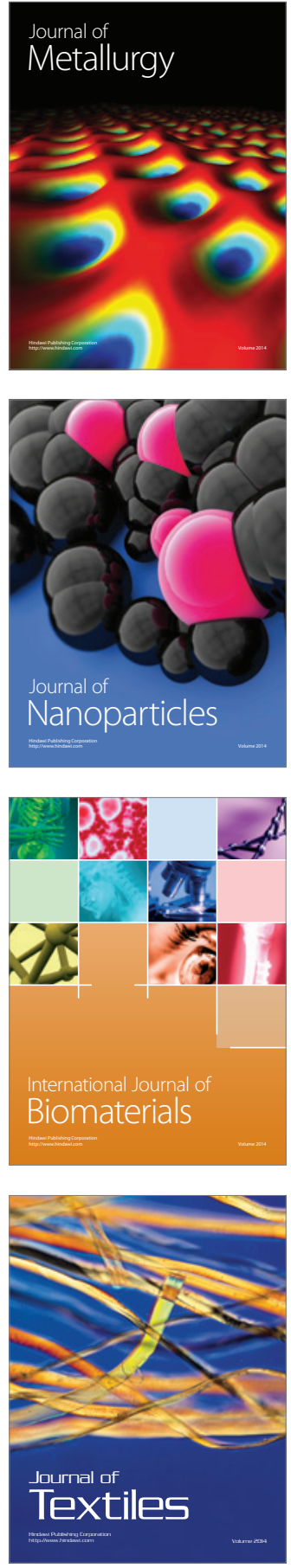